\title{
The risk of post-intensive care syndrome among patients hospitalised in the intensive care unit
}

\section{Ryzyko wystapienia zespołu stresu po intensywnej terapii u pacjentów hospitalizowanych na oddziale intensywnej terapii}

\author{
Katarzyna Białek \\ Institute of Medical Sciences, Collegium Medicum, Jan Kochanowski University, Kielce, Poland \\ Head of the Institute: Beata Kręcisz MD, PhD, Prof. UJK
}

Key words: intensive care unit, post-intensive care syndrome, stress, depression, anxiety.

Słowa kluczowe: intensywna terapia, zespół stresu po intensywnej terapii, stres, depresja, lęk.

\begin{abstract}
The development of medicine and the improvement of techniques used for life support in intensive care units (ICUs) have significantly contributed to reducing the mortality of treated patients. On the other hand, many of them experience reduced quality of life and health problems after discharge from the unit. Individuals who have undergone a critical illness requiring intensive care have reported physical weakness, mental health problems, and a decrease in cognitive functions. It has been proposed that this form of reaction of patients treated in the ICU should be called post-intensive care syndrome (PICS). Understanding and early diagnosis of PICS may therefore be important for the medical personnel and for the patient and his/her family. This article describes the reactions and health consequences of patients treated in the ICU and how to prevent them.
\end{abstract}

\section{Streszczenie}

Rozwój medycyny i udoskonalenie technik podtrzymujących życie na oddziałach intensywnej terapii (OIT) znacząco przyczyniły się do zmniejszania śmiertelności leczonych pacjentów. Wielu jednak z nich doświadcza obniżonej jakości życia i problemów zdrowotnych po wypisaniu z oddziału i zakończeniu hospitalizacji. Osoby, które przeszły krytyczną chorobę, zgłaszały pogorszenie funkcjonowania fizycznego, problemy ze zdrowiem psychicznym i osłabienie funkcji poznawczych. Zaproponowano, aby taką formę reakcji chorych leczonych na OIT nazwać zespołem stresu po intensywnej terapii (PICS). Zrozumienie i wczesna diagnoza PICS moga być pomocne nie tylko dla pacjenta i jego rodziny, lecz także dla personelu medycznego. W artykule opisano reakcje i konsekwencje zdrowotne pacjentów leczonych na OIT oraz sposoby zapobiegania ich wystąpieniu.

\section{Introduction}

The development of medicine and the improvement of tools and techniques used for life support in intensive care units (ICUs) have significantly contributed to reducing the mortality of treated patients. On the other hand, many of them experience reduced quality of life and health problems after discharge from the unit. Individuals who have undergone a critical illness requiring intensive care have reported physical weakness [1, 2], mental health problems [3, 4], and a decrease in cognitive functions [5].

Studies have shown that after completion of ICU hospitalisation, such complaints as polyneuropathy and myopathy, dysphagia, cachexia, multi-organ dysfunction, chronic pain [6], reduced sexual function [7], depression, anxiety, post-traumatic stress disorder
(PTSD) [8], and impairment of executive functions [9] may occur. These problems significantly affect daily functioning.

In view of the above, the Society of Critical Care Medicine has proposed that this form of reaction of patients treated in the ICU should be called post-intensive care syndrome (PICS). This term describes new or worsening physical capacity dysfunctions, cognitive deficits, or mental health deterioration persisting after hospitalization in an intensive care unit [10]. The recognition of this syndrome has increased the interest of specialists not only in the aspect of treatment and reduced mortality of treated patients, but also in the improvement of performance and quality of life after intensive care in the long-term aspect [11]. The term PICS is also used among close family members of ICU patients as post-intensive care syndrome-family 
(PICS-f) [12] and among parents of children treated in the intensive care unit as post-intensive care syndrome-paediatrics (PICS-p) [13], who have subsequent adverse effects on mental health such as sleep problems, anxiety, depression, or complicated mourning.

This article describes the reactions and health consequences of patients treated in the ICU and how to prevent them, taking into account the conditions of the ward and possibilities after the end of hospitalization.

\section{Psychological reactions of patients treated in the intensive care unit}

Patients treated in the intensive care unit may experience a number of adverse reactions and psychological complications. Studies have shown that the incidence of anxiety and depression symptoms may increase by $40 \%$ and $30 \%$, respectively, in ICU survivors [14]. Moreover, the prevalence of anxiety varies from $12 \%$ to $43 \%$ [15], depression from $10 \%$ to $30 \%$ [16] and $5 \%$ to $64 \%$ of symptoms associated with PTSD [17], which may persist for up to 8 years after the end of hospitalisation [18].

The most common risk factors for anxiety or depression are past mental illness, duration of mechanical ventilation, length of ICU stay, chronic pain [after: 18], female gender, age, and education [14]. There are also studies suggesting that hypoglycaemia and hypoxia during ICU treatment may also contribute to depression $[19,20]$. Another factor may be the severity of the injury. Studies in which patients were observed 1 year after a severe ICU injury showed up to $30 \%$ of PTSD, up to $40 \%$ of anxiety, and up to $30 \%$ of depression symptoms [21]. This may be related to the injury itself or the surgical intervention undertaken. The accompanying symptoms of anxiety, depression, and PTSD were also present after 3 months in almost a third of survivors of delirium during the treatment in the ICU [22].

According to the literature, memories from intensive care treatment are also crucial. It was noted that almost half of the patients did not remember the time of admission and almost 30\% declared amnesia during their entire stay. However, this percentage decreased when the treated patients were asked if they remembered any of the moments of intensive care treatment. Almost half of those who survived hospitalization in the ICU also reported nightmares during their stay in the ICU; moreover, as many as $14 \%$ of the respondents declared that they experienced them even 6 months after discharge. This is all the more important because these patients showed a much higher risk of depression and/or PTSD [23].

From the psychological point of view, the course of mental reactions after intensive therapy may also be influenced by the patient's personality. Patients who are optimistic about the treatment and the course of hospitalization are more able to recover, recover faster, suffer less mentally, and have a better quality of life [24].

\section{Decreased cognitive functions and physical problems}

Another aspect of PICS is the weakening of cognitive functions. The severity of neurocognitive deficits ranges from subtle difficulties in performing complex tasks to profound inefficiencies in everyday activities [11].

The factors contributing to cognitive impairment in ICU patients include prolonged or frequent periods of hyper- or hypoglycaemia, longer and deeper hypoxia, delirium, and cognitive deficits existing before ICU admission [14, 25, 26].

The literature reports that cognitive dysfunction occurs in $30 \%$ to $80 \%$ of patients treated in the ICU and includes problems with memory and concentration, visual and spatial perception, information processing, planning, and problem solving. These may improve within a few months, but $25 \%$ of people with acute respiratory distress syndrome (ARDS) still have cognitive impairment even 6 years after completing their ICU treatment. An equally high percentage of permanent cognitive impairment has been observed in individuals over 65 years of age and/or with past sepsis, where cognitive impairment may occur up to 8 years after discharge from the ward [18]. It is worth noting, however, that the course of acquired cognitive deficits usually does not progress; moreover, they may even improve over time [14].

The impairment of neurocognitive functions after ICU hospitalisation significantly contributes to the dysfunction of daily functioning and compliance with the recommendations after discharge (e.g. those concerning drug use, systematic check-ups), which may also delay the recovery [11]. It is also noted that the professional and social functioning decreases for this reason.

The second group of dysfunctions related to PICS are physical problems, such as difficulties in maintaining balance or muscle weakness. Each additional day of lying in bed in the intensive care unit is associated with an $11 \%$ decrease in muscle strength even after 24 months of observation [27], which may result in reduced mobility of treated patients and increased risk of falls.

It is estimated that physical problems occur in 25\% to $80 \%$ of patients treated in the ICU [18]. Moreover, studies have shown that $45.2 \%$ of patients had at least moderate mobility problems at the end of their hospitalization, and $61.3 \%$ had serious problems with everyday functioning in this area [28, 29].

The decrease in physical functioning occurred mainly 3 months after leaving the ICU. However, the first year was followed by a slow but steady improvement in functioning [30]. The problems with movement, difficulties in performing daily activities, pain, and a decrease in physical capacity were most frequently reported [31]. The factors affecting poor functioning were longer stay in the ICU, severity of the 
disease, and sleep problems. Greater difficulties were also reported by elderly people [19]. The influence of age on physical problems after ICU discharge is however variable. Some studies report that despite poor objective outcome, these patients have good physical functioning, and only $12 \%$ of survivors were dissatisfied 5 years after discharge. This seems to be related to the acceptance of the disease and a more constructive adaptation to long-term functional disabilities in this group $[23,30]$. Some analyses even report that subjective evaluation of physical functioning is better than in younger patients [32]. This discrepancy is likely to be associated with greater acceptance of age-related limitations and coping ability compared to younger patients. Moreover, it can be assumed that older patients have lower expectations of quality of life after a critical illness.

The lower physical functioning is associated with difficulties not only for the patients being treated, but also for their families and caregivers. This is all the more important because as many as a quarter of patients need about $6 \mathrm{~h}$ of help during the day up to 12 months after ICU discharge [17]. Interestingly, however, Cullen et al. [33] described the 1-year survival time of 226 critically ill patients in the ICU after surgery and showed that as many as $42 \%$ of them were as efficient as before admission, and only $18 \%$ of them declared that they needed help at home. However, it is worth mentioning that the study involved patients with an average length of stay in the ICU of less than 3 days, which may significantly affect their functioning compared to those who have been treated in the ward longer and in worse health. This is confirmed by studies by Fakhry et al. [34], in which it was noted that the majority of patients after a longer ICU stay (26 days) were discharged from the hospital to the rehabilitation centre. However, after 18 months $72 \%$ of patients in this study functioned independently. Most care was declared by patients with a 48 -hour period of mechanical ventilation [35].

\section{Prevalence of PICS among patients treated in the ICU}

Identification of symptoms consistent with the diagnosis of the post-intensive care syndrome may be difficult because there is limited continuity of care between ICU, rehabilitation or nursing facilities, and home care. However, studies conducted so far have shown a high prevalence of PICS symptoms among patients treated in the intensive care unit.

Maley et al. [36] conducted a telephone assessment of cognitive, physical, and mental functions among 43 patients who were on average 8 months after a critical disease. At least 1 PICS problem occurred in $84 \%$ of patients. They also reported that 2 or more PICS problems occurred in 56\% of patients. Marra et al. [37] evaluated the co-occurrence of PICS in 406 patients during the $3^{\text {rd }}$ and $12^{\text {th }}$ months after discharge. It was shown that $64 \%$ and $56 \%$ of the patients treated had 1 or more PICS disorders after 3 and 12 months, respectively. It was also found that the co-occurrence of dysfunction in 2 or more domains is common, with cognitive and psychological problems being most persistent over time. An equally high incidence of PICS was reported by Kawakami et al. [38]. The prevalence of PICS 6 months after ICU admission was $64 \%$ among 96 adults who survived ICU stay. New or increased physical, mental, and cognitive disorders occurred in 33.3\%, 14.6\%, and $37.5 \%$ of patients, respectively. The percentage of patients with 2 or more PICS symptoms was 19.9\%.

Interestingly, people with higher education had a lower risk of developing post-intensive care syndrome. However, the exact mechanisms through which education can protect against this problem are unclear. This may be due to the fact that higher education is associated with professional achievement, better cognitive skills, as well as a wider support network, which may provide more resources to facilitate recovery [37].

It is worth noting that the prevalence of PICS, in addition to its health effects, also has socio-economic consequences. In the long-term perspective, only $49 \%$ of survivors returned to work 1 year after discharge from the hospital. This number increased to $73 \%$ after 5 years [30]. However, about $65 \%$ of patients who reported more severe symptoms of PICS did not return to their previous activity/employment levels at all [39]. Moreover, studies conducted among patients treated in the UK ICU showed that 1 year after discharge from the hospital $22 \%$ of patients still required the assistance of a carer in daily care, and as many as $28 \%$ of respondents reported a negative impact of ICU stay and convalescence on family income [14]. A decrease in employment in $50 \%$ of people treated in the ICU was also demonstrated by studies conducted in the United States [40]. Moreover, $50 \%$ of ARDS patients did not return to work at all 1 year after discharge, and only about $10 \%$ of patients undergoing mechanical ventilation for more than 4 days were professionally active 1 year after the end of treatment [after:18].

\section{Quality of life of patients treated in the ICU}

Patients in the ICU often also report a lower Health-Related Quality of Life (HRQOL) than before hospitalization. HRQOL decreased in almost all assessed domains for at least 6 months after the end of hospitalization [31]. Although a clinically significant improvement is observed up to 5 years after discharge, these indicators are still lower for many patients than in other population standards [30, 31].

The higher risk of reduced quality of life at the end of hospitalisation is associated with the diagnosis, the severity of the disease, age, pre-admission 
health status [41, 42], the presence of chronic heart failure and/or cancer, severe multi-organ trauma or neurological problems, and the length of hospitalisation [23, 32]. Differences between categories of ICU admissions have also been noted. Significantly reduced HRQOL scores 12 months after admission were found in patients with multi-organ failure, 16 months with sepsis, and 18 months in patients after trauma [43]. In a systematic review of the quality of life of adult survivors of the critical disease, Dowdy et al. [19] referred to 6 studies in which patients after scheduled and emergency surgery were analysed. The latter showed a much worse quality of life. However, Abelha et al. [44] did not find such a relationship. This may be due to the fact that as many as $85 \%$ of the patients in this study were subjected to scheduled surgery only, which is too unreliable in statistical terms. However, the best quality of life was assessed by patients after elective surgery, and the worst by patients with chronic respiratory failure and after multi-organ trauma [45]. Research also suggests an impact of chronic diseases on quality of life after ICU. However, these findings are inconsistent. For example, Yinnon et al., in a study of 126 critically ill patients, showed that their quality of life after 6 months did not deteriorate compared to the assessment of their health status 1 week before admission to the ICU. However, much worse results were recorded in patients in a lifethreatening condition [after: 42]. In other studies, improvement in results between 3 and 12 months in surgical patients was found [46]. This may be due to the relief of symptoms after surgery and, consequently, to better physical, mental, and social functioning. It is particularly interesting that younger patients, especially after orthopaedic injuries, showed a much lower quality of life. Interpretation of this state of affairs may be difficult, but it seems that it may be related to previous employment and difficulty or complete inability to return to work after undergoing intensive care treatment [42]. The quality of life after ICU stay also depends on the patient's condition before hospitalization. Patients who were previously physically fit experienced a significant decline after the disease. In contrast, those with pre-existing poor health showed improvement within 6 months of admission to the ward. It was associated with a lower intensity or complete pain relief after surgery and, consequently, better mental and social functioning [42]. Analyses of patient survival after intensive care treatment are also important in research on the quality of life [46]. The greatest attention was paid to the mortality 1 year after discharge. Interesting research in this regard was carried out by Eddleston et al. [47]. Mortality was reported to be $39 \%$ after 3 months of follow-up, $41 \%$ after 6 months, and 53\% after 1 year. In turn, $57 \%$ of respondents survived for over a year. Similar indicators after 1 year of survival were obtained in the studies by Jacobs et al. [48]. It is also worth citing the research by
Ridley and Plenderleith [49], who indicated a 3-fold higher risk of death in the first year after ICU treatment compared to the general population. Compared to younger ICU patients, older people show higher mortality, which reaches the maximum in the first 3 months after discharge from the ICU and may persist from 2 to as much as 15 years after discharge.

\section{COVID-19 and post-intensive care syndrome}

PICS and the novel SARS-CoV2 virus causing COVID-19 pose a serious threat to public health. It can be expected that patients treated in the ICU because of the diagnosed coronavirus will be particularly vulnerable to the risk of PICS and the prevalence of depression, anxiety, PTSD, and fatigue might be high in these patients; however, data on these diagnoses in patients with COVID-19 are preliminary or unpublished.

According to the literature, at least $20 \%$ of patients with COVID-19 require hospitalization in the intensive care unit, and thus an average of 10 days of supportive care using mechanical ventilation. This is important because about $50 \%$ of all patients, of all ages, admitted to the ICU requiring mechanical ventilation develop PICS $[27,50]$. Moreover, ICU patients with COVID-19 also have a high incidence of delirium due to the presence of encephalopathy, sepsis, and the need for intubation [51]. The longer a patient remains in the ICU in a life-threatening condition, the greater the risk of long-term physical, cognitive, and emotional complications.

It is also worth noting that in order to minimize the spread of COVID-19 in wards, many hospitals have applied restrictive rules for patient visits, which means that most of them, and especially those infected with COVID-19, spend their hospitalization in complete isolation. Although these measures are understandable and necessary, the consequences for mental health can be significant. This is why early prevention of PICS and the development of an interdisciplinary support system for patients hospitalized in the ICU is so important, also in the context of the consequences and effects of the COVID-19 pandemic.

\section{PICS prevention}

Prevention and implementation of PICS treatment plans should involve interdisciplinary care by engaging various specialists, including physiotherapists and psychologists.

Given the syndrome of PICS symptoms, the risk analysis should include cognitive, psychiatric, and physical assessment of the treated patient. Fast and easy to interpret neuropsychological and psychological screening tests such as Montreal Cognitive Assessment (MOCA), Addenbrooke's Cognitive Examination III (ACE-III), or Mini Mental State Examination (MMSE) can be used to assess cognitive disorders and the Hospital Anxiety and Depression Scale (HADS), Beck's De- 
pression Scale, or Geriatric Depression Scale (GDS) to assess the severity of anxiety and/or depression.

In the area of PICS risk minimization, the ABCDEF Liberation Collaboration care system activated in the ICU, which includes assessing pain (A), both spontaneous awakening and breathing trials (B), choice of drugs (C), delirium monitoring/management (D), early exercise/mobility (E), and family empowerment (F), is of key significance. Studies involving more than 1500 patients treated in the ICU have shown that the use of ABCDEF significantly reduces the risk of death within 7 days of admission and the occurrence of PICS symptoms [52].

Another proposed method is the use of logs, i.e. written chronological reports from the ICU stay, which are made available to patients and their families during hospitalization. Because patients often have limited or distorted memories of their ICU experience due to sedation and delirium, these logs may enable patients to assess their recovery [53]. According to the literature, the use of ICU logs has been associated with a reduced risk of anxiety and depression in ICU survivors and improved HRQOL at the end of hospitalisation. Some analyses suggest that ICU logs also reduced the risk of PTSD development in family members of treated patients, although the research in this area is ambiguous [14].

It also seems important to involve the psychologist in the ward's work and to pay special attention to environmental factors of intensive therapy, i.e. appropriate lighting and temperature in the room, reduction of noise and alarms, as well as family involvement in patient care.

\section{Summary}

The article describes the psychological aspect of intensive care therapy, rarely discussed in Polish literature, and presents the most important issues related to staying in the ICU in the assessment of multidimensional and long-term prospects of the treated patients. This is important because the ICU is one of the places in the hospital that has a deeper impact on patients and family members, especially due to the use of advanced technology or the constant presence of health professionals monitoring the life functions of treated patients.

On the basis of the above-mentioned analyses, it is clear that the health consequences of patients treated in the ICU are not limited to the period of hospitalization, and the requirements for the patient and his or her caregivers do not end after discharge. In fact, the intensity of negative emotions and situations often increases after the patient's discharge. This is a particularly difficult transition period, which can lead to a new phase of complex and unpredictable disease experiences. In addition, health care support is gradually diminishing, and family carers are taking on more and more responsibilities for the patient [3].
Therefore, given the importance of the problem and in an attempt to define preventive strategies, the American College of Critical Care Medicine Task Force has developed clinical practice guidelines in this area. One of them is family involvement and support in patient care during and after ICU admission [10]. In 2010, in the Netherlands, one of the first outpatient clinics was established for patients after intensive care hospitalisation. Its primary goal was not only to provide families with multidimensional specialist care, but above all also to raise awareness and better understand the problems associated with the intensive care unit and support them in their care after discharge from the hospital [54]. From a health resources point of view, such activities allow for the early detection of PICS and the implementation of targeted interventions for those most in need. A better understanding of PICS factors is therefore essential to analyse this phenomenon. However, further verification is needed. It seems that the analysis of the reaction of family members of patients treated in the ICU can also help to interpret the experience and needs of the intensive care unit.

The key is to recognize the symptoms of PICS at the earliest possible stage. This can also be facilitated by education of medical personnel. It is also important to provide patients and their closest relatives with multi-specialist care, not only from a doctor and a nurse, but also from a physiotherapist or psychologist, who should monitor the psychophysical condition of the patient being treated and their closest relatives on a long-term basis. There are even papers available in the literature specifically aimed at the role of the psychologist in the intensive care unit. One of them is a study within the Health Service Humanization Project, conducted by Pontificia Universidad Javeriana between 1994 and 2000 [55]. With regard to the assessment of the psychological work by patients and their closest, most of them found it very necessary and demanded more time for this service. It should be noted, however, that these psychologists did not work full-time in the ICU because their work was only a form of project. Regardless of this context, however, this indicates the need for the hospitals to have psychologists as part of the ICU team.

Understanding and early diagnosis of PICS may therefore be important not only for the medical personnel working with the patient, but above all for the patient and his/her family. The repetitiveness of such observations would allow conclusions to be drawn about the specificity of functioning after hospitalization in the intensive care unit and, consequently, would help to construct effective algorithms of management and develop adequate support programs for the treated patients.

\section{Conflict of interest}

The author declares no conflict of interest. 


\section{References}

1. Fan E, Dowdy DW, Colantuoni E, Mendez-Tellez PA, Sevransky JE, Shanholtz C, Dennison Himmelfarb CR, Desai SV, Ciesla N, Herridge MS, Pronovost PJ, Needham DM. Physical complications in acute lung injury survivors: a two-year longitudinal prospective study. Crit Care Med 2014; 42: 849-859.

2. Denehy L, Berney S, Whitburn L, Edbrooke L. Quantifying physical activity levels of survivors of intensive care: a prospective observational study. Phys Ther 2012; 92: 1507-1517.

3. Choi J, Tate JA, Rogers MA, Donahoe MP, Hoffman LA. Depressive symptoms and anxiety in intensive care unit (ICU) survivors after ICU discharge. Heart Lung 2016; 45: 140-146.

4. Parker AM, Sricharoenchai T, Raparla S, Schneck KW, Bienvenu OJ, Needham DM. Posttraumatic stress disorder in critical illness survivors: a metaanalysis. Crit Care Med 2015; 43: 1121-1129.

5. Pandharipande PP, Girard TD, Jackson JC, Morandi A Thompson JL, Pun BT, Brummel NE, Hughes CG, Vasilevskis EE, Shintani AK, Moons KG, Geevarghese SK, Canonico A, Hopkins RO, Bernard GR, Dittus RS, Ely EW, BRAIN-ICU Study Investigators. Long-term cognitive impairment after critical illness. N Engl J Med 2013; 369:1306-1316

6. Kondo Y, Fuke R, Hifumi T, Hatakeyama J, Takei T, Yamakawa K, Inoue S, Nishida O. Early rehabilitation for the prevention of post-intensive care syndrome in critically ill patients: a study protocol for a systematic review and metaanalysis. BMJ Open 2017; 7: e013828.

7. Ulvik A, Kvåle R, Wentzel-Larsen T, Flaatten H. Sexual function in ICU survivors more than 3 years after major trauma. Intensive Care Med 2008; 34: 447-453.

8. Myhren H, Ekeberg Ø, Tøien K, Karlsson S, Stokland O. Posttraumatic stress, anxiety and depression symptoms in patients during the first year post intensive care unit discharge. Crit Care 2010; 14: R14.

9. Torgersen J, Hole JF, Kvåle R, Wentzel-Larsen T, Flaatten H. Cognitive impairments after critical illness. Acta Anaesthesiol Scand 2011; 55: 1044-1051.

10. Davidson JE, Harvey MA, Schuller J, Black G. Post-intensive care syndrome: what to do and how to prevent it. American Nurse Today 2013; 8: 32-38.

11. Lechowicz K, Drożdżal S, Karolak I, Kotfis K. PICS - Post-intensive care syndrome - zespół zaburzeń po intensywnej terapii PICS - Post-intensive care syndrome. Anestezjol Ratown 2019; 13: 89-96.

12. Davidson JE, Jones C, Bienvenu OJ. Family response to critical illness: post-intensive care syndrome-family. Crit Care Med 2012; 40: 618-624.

13. Manning JC, Pinto NP, Rennick JE, Colville G, Curley MAQ. Conceptualizing post intensive care syndrome in children-the PICS-p framework. Pediatr Crit Care Med 2018; 19: 298-300.

14. Smith S, Rahman O. Post Intensive Care Syndrome (PICS) [Updated 2020 Jun 25]. In: StatPearls [Internet]. Treasure Island (FL): StatPearls Publishing; 2020 Jan-. Available from: https://www.ncbi.nlm.nih.gov/books/NBK558964/.

15. Scragg P, Jones A, Fauvel N. Psychological problems following ICU treatment. Anaesthesia 2001; 56: 9-14.

16. Davydow DS, Gifford JM, Desai SV, Bienvenu OJ, Needham DM. Depression in general intensive care unit survivors: a systematic review. Intensive Care Med 2009; 35: 796-809.

17. Griffiths J, Fortune G, Barber V, Young JD. The prevalence of posttraumatic stress disorder in survivors of ICU treatment: a systematic review. Intensive Care Med 2007; 33: 1506-1518.

18. Harvey MA, Davidson JE. Post-intensive care syndrome: right care, right now... and later. Crit Care Med 2016; 44: 381-385.

19. Dowdy DW, Dinglas V, Mendez-Tellez PA, Bienvenu OJ, Sevransky J, Dennison CR, Shanholtz C, Needham DM. Intensive care unit hypoglycemia predicts depression during early recovery from acute lung injury. Crit Care Med 2008; 36: 2726-2733.

20. Zhao F, Yang J, Cui R. Effect of hypoxic injury in mood disorder. Neural Plast 2017; 2017: 6986983.

21. Peris A, Bonizzoli M, Iozelli D, Migliaccio ML, Zagli G, Bacchereti A, Debolini M, Vannini E, Solaro M, Balzi I, Bendoni E, Bacchi I, Trevisan M, Giovannini V, Belloni L. Early intra-intensive care unit psychological intervention promotes recovery from post-traumatic stress disorders, anxiety and depression symptoms in critically ill patients. Crit Care 2011; 15: R41.

22. Wang S, Allen D, Kheir YN, Campbell N, Khan B. Aging and post-intensive care syndrome: a critical need for geriatric psychiatry. Am J Geriatr Psychiatry 2018; 26: 212-221.

23. Granja C, Lopes A, Moreira S, Dias C, Costa-Pereira A, Carneiro A. Patients' recollections of experiences in the intensive care unit may affect their quality of life. Critical Care 2005; 9: R96-R109.

24. Duckworth AL, Peterson C, Matthews MD, Kelly DR. Grit: perseverance and passion for long-term goals. J Pers Soc Psychol 2007; 92: 1087-1101.

25. Inoue $S$, Hatakeyama J, Kondo Y, Hifumi T, Sakuramoto H, Kawasaki T, Taito S, Nakamura K, Unoki T, Kawai Y, Kenmotsu Y, Saito M, Yamakawa K, Nishida O. Post-intensive care syndrome: its pathophysiology, prevention, and future directions. Acute Med Surg 2019; 6: 233-246.

26. Hopkins RO, Weaver LK, Pope D, Orme JF, Bigler ED, Larson-LOHR V. Neuropsychological sequelae and impaired health status in survivors of severe acute respiratory distress syndrome. Am J Respir Crit Care Med 1999; 160: 50-56.

27. McPeake J, Hirshberg EL, Christie LM, Drumright K, Haines K, Hough CL, Meyer J, Wade D, Andrews A, Bakhru R, Bates S, Barwise JA, Bastarache J, Beesley SJ, Boehm LM, Brown S, Clay AS, Firshman P, Greenberg S, Harris W, Hill C, Hodgson C, Holdsworth C, Hope AA, Hopkins RO, Howell DCJ, Janssen A, Jackson JC, Johnson A, Kross EK, Lamas D, MacLeod-Smith B, Mandel R, Marshall J, Mikkelsen ME, Nackino M, Quasim T, Sevin CM, Slack A, Spurr R, Still M, Thompson C, Weinhouse G, Wilcox ME, Iwashyna TJ. Models of Peer Support to Remediate Post-Intensive Care Syndrome: A Report Developed by the SCCM Thrive International Peer Support Collaborative. Crit Care Med 2019; 47: e21-e27.

28. De Jonghe B, Sharshar T, Lefaucheur JP, Authier FJ, Durand-Zaleski I, Boussarsar $\mathrm{M}$, Cerf $\mathrm{C}$, Renaud E, Mesrati F, Carlet J, Raphaël JC, Outin H, Bastuji-Garin S; for the Groupe de Réflexion et d'Etude des Neuromyopathies en Réanimation. Paresis acquired in the intensive care unit: a prospective multicenter study. JAMA 2002; 288 : 2859-2867. 
29. Cody N, Lakey S, McMahon S, Downey MK, Duncan MS Hewitt JA, Simpson CB, Duffy MJ, O'Reilly RF, Johnston P, Silversides JA. Clinical characteristics and post-intensive care outcomes of COVID-19 pneumonia. Crit Care Emerg Med 2020; 10.21203/rs.3.rs-58685/v1.

30. Cuthbertson B, Roughton S, Jenkinson D, MacLennan G, Vale L. Quality of life in the five years after intensive care: a cohort study. Critical Care 2010; 14: R6.

31. McKinley S, Fine M, Elliott R, Elliott D. Health-related quality of life and associated factors in intensive care unit survivors 6 months after discharge. Am J Crit Care 2016; 25: 52-58.

32. Conti M, Merlani P, Ricou B. Prognosis and quality of life of elderly patients after intensive care. Swiss Med Wkly 2012; 142: w13671.

33. Cullen DJ, Ferrara LC, Briggs B. Survival, hospitalization charges and follow-up results in critically ill patients. N Engl J Med 1976; 294: 982.

34. Fakhry SM, Kercher KW, Rutledge R. Survival, quality of life, and charges in critically ill surgical patients requiring prolonged ICU stays. J Trauma 1996; 41: 999-1007.

35. Im K, Belle SH, Schulz R, Mendelsohn AB, Chelluri L. Prevalence and outcomes of caregiving after prolonged ( $\geq 48$ hours) mechanical ventilation in the ICU. Chest 2004; 125: 597-606.

36. Maley JH, Brewster I, Mayoral I, Siruckova R, Adams S, McGraw KA, Piech AA, Detsky M, Mikkelsen ME. Resilience in survivors of critical illness in the context of the survivors' experience and recovery. Ann Am Thorac Soc 2016; 13: 1351-1360.

37. Marra A, Pandharipande PP, Girard TD, Patel MB, Hughes CG, Jackson JC, Thompson JL, Chandrasekhar R, Ely EW, Brummel NE. Co-occurrence of post-intensive care syndrome problems among 406 survivors of critical illness. Crit Care Med 2018; 46: 1393-1401.

38. Kawakami D, Fuijtani S, Morimoto T, Dote H, Takita M, Takaba A, Hino M, Nakamura M, Irie H, Adachi T, Shibata M, Kataoka J, Korenaga A, Yamashita T, Okazaki T, Okumura M, Tsunemitsu T. Prevalence of post intensive care syndrome among japanese intensive care unit patients: a prospective, multicenter, observational J-PICS study. Crit Emerg Med 2021; 25: 69.

39. Sukantarat KT, Brett S. The neuropsychological consequences of intensive care. In: Surviving Intensive Care. Update in Intensive Care and Emergency Medicine. Angus D, Carlet J (eds.). Springer Heidelberg 2003; 51-61.

40. Norman BC, Jackson JC, Graves JA, Girard TD, Pandharipande PP, Brummel NE, Wang L, Thompson JL, Chandrasekhar R, Ely EW. Employment outcomes after critical illness: an analysis of the bringing to light the risk factors and incidence of neuropsychological dysfunction in ICU Survivors Cohort. Crit Care Med 2016; 44: 2003-2009.

41. Chelluri L, Im KA, Belle SH, Schulz R, Rotondi AJ, Donahoe MP, Cirio CA, Medelsohn AB, Pinsky MR. Long-term mortality and quality of life after prolonged mechanical ventilation. Crit Care Med 2004; 32: 61-69.

42. Djaiani G, Ridley S. Outcome of intensive care in the elderly. Anaesthesia 1997; 52: 1130-1136.

43. Holbrook TL, Anderson JP, Sieber WJ, Browner D, Hoyt DB. Outcome after major trauma: 12-month and 18-month follow-up results from the Trauma Recovery Project. J Trauma 1999; 46: 765-771.
44. Abelha FJ, Santos C, Maia PC, Castro MA, Barros H. Ouality of life after stay in surgical intensive care unit. BMC Anesthesiology 2007; 7: 8.

45. Basińska K. Ocena wyników leczenia oraz jakości życia chorych po intensywnej terapii w stanach zagrożenia życia. Gdańsk 2005. Niepublikowana rozprawa na stopień doktora nauk medycznych.

46. Lipsett PA, Swoboda SM, Dickerson J, Ylitalo M, Gordon T, Breslow M, Campbell K, Dorman T, Pronovost P, Rosenfeld B. Survival and functional outcome after prolonged intensive care unit stay. Ann Surg 2000; 231: 262-268.

47. Eddleston JM, White P, Guthrie E. Survival, morbidity, and quality of life after discharge from intensive care. Crit Care Med 2000; 28: 2293-2299.

48. Jacobs CJ, van der Vliet JA, van Roozendaal MT, van der Linden CJ. Mortality and quality of life after intensive care for critical illness. Intensive Care Med 1988; 14: 217-220.

49. Ridley S, Plenderleith L. Survival after intensive care. Anaesthesia 1994; 49: 933935.

50. Stam HJ, Stuck G, Bickenbach J. COVID-19 and post intensive care syndrome: a call for action. J Rehabil Med 2020; 52: jrm00044.

51. Kotfis K, Williams Roberson S, Wilson JE, Dabrowski W, Pun BT, Ely EW. COVID-19: ICU delirium management during SARS-CoV-2 pandemic. Crit Care 2020; 24: 176.

52. Pun BT, Balas MC, Barnes-Daly MA, Thompson JL, Aldrich JM, Barr J, Byrum D, Carson SS, Devlin JW, Engel HJ, Esbrook CL, Hargett KD, Harmon L, Hielsberg C, Jackson JC, Kelly TL, Kumar V, Millner L, Morse A, Perme CS, Posa PJ, Puntillo KA, Schweickert WD, Stollings JL, Tan A, D'Agostino McGowan L, Wesley Ely E. Caring for critically Ill patients with the ABCDEF bundle: results of the ICU liberation collaborative in over 15,000 adults. Crit Care Med 2019; 47: 3-14.

53. Blair T, Eccleston SD, Binder HM, McCarthy MS. Improving the patient experience by implementing an ICU diary for those at risk of post-intensive care syndrome. J Patient Exp 2017; 4: 4-9.

54. Dettling-Ihnenfeldt DS, de Graaff AE, Nollet F, van der Schaaf M. Feasibility of post-intensive care unit clinics: An observational cohort study of two different approaches. Minerva Anestesiologica 2015; 81: 865-875.

55 . Novoa MB, Ballesteros de Valderrama BP. The role of psychologist in an intensive care unit. Univ Psychol Bogotá 2006; 5: 599-612.

\section{Address for correspondence:}

\section{Katarzyna Białek}

Institute of Medical Sciences

Collegium Medicum

Jan Kochanowski University

E-mail: katarzynabialek@vp.p 